\title{
Migration and Migrants Entrepreneurial Skills in South Africa: Assets or Liabilities?
}

\author{
Mr. Vivence Kalitanyi \\ Department of Retail Business Management, Faculty of Business, Cape Peninsula \\ University of Technology, South Africa. Email: kalitanyiv@cput.ac.za
}

Prof. Kobus Visser (Ph.D)

School of Business and Finance (SBF), Economic and Management Sciences, University of the Western Cape, South Africa.Email: kvisser@uwc.ac.za

\section{Doi:10.5901/mjss.2014.v5n14p147}

\section{Abstract}

Cape Town's CBD, as well as many of its suburbs, is a location that hosts many immigrant entrepreneurs. An empirical research was conducted in these areas to determine the impact of those immigrant entrepreneurs with regards to the transmission of entrepreneurial skills to local citizens. Literature on migration and its consequences was reviewed. A questionnaire as a research instrument was drawn up and pilot-tested. A sample of 120 immigrants was used, and face-to-face interviews were conducted. Findings revealed that more than $73 \%$ of immigrant entrepreneurs transmit their entrepreneurial skills to locals who are either employed by them or do business with them. The study also revealed that $82 \%$ of the immigrant entrepreneurs' employees are locals, of whom 54\% have ascertained to have acquired entrepreneurial skills from their employers. The study was conducted only in Cape Town and some of its suburbs, and therefore does not represent the general trend in the whole country. Furthermore, the study involved only those immigrants from the African continent. The overall result is an acknowledgment of the contribution that foreigners are making on skills development and to the country's growth. In conclusion, recommendations relevant to policy change on South African immigration law are made, as well as suggestions offered for government intervention in teaching tolerance and peaceful cohabitation between foreigners and locals.

Keywords: entrepreneurship, migration, immigrant entrepreneur, entrepreneurial skills transmission, Cape Town.

\section{Introduction}

With a $15 \%$ university graduation rate -according to Letseka and Maile (2008:3), one of the lowest in the world--South Africa still faces a huge challenge with regards to providing the necessary skills in many fields. The shortage of skills is not only felt in natural sciences and in engineering but it is also a reality in some social sciences, such as entrepreneurship, and this constitutes a major setback to the government initiatives for job creation. O'Neill and Viljoen (2001:37) maintained that entrepreneurs may be considered as the most important prerequisite for economic development in a country, and without them, the state has the difficult task of organising development without the incentive of potential gain. This is indeed a major hindrance to job creation and economic development and results in a severe lack of employment opportunities.

On the other side, the presence of many foreign nationals in South Africa, and their involvement in small business activities, continues to attract different social organisations and academics alike to investigate the extent to which their entrepreneurial activities benefit local citizens. Ordinary people are becoming more and more intolerant, displaying an aggressive and sometime brutal attitude towards immigrants while making all sort of negative comments. On the other hand, foreign migrant entrepreneurs, who mostly survive by their entrepreneurial initiatives in order to satisfy their basic needs, claim to help locals. This article is aimed at contributing to the debate, by reporting on an investigation concerning the extent to which immigrants' entrepreneurial skills are transmitted to locals.

The article is presented in the following format: In the next section, the theoretical arguments linking migration and some of its consequences to the host population is developed, followed by a description of the methodology used to carry out the research. In the final section, the results of empirical research are presented, followed by a discussion. The article ends with recommendations to various stakeholders who deal with migrants in South Africa. 


\section{Debate around Migration}

\subsection{Diverging opinions: for or against migration?}

People within a country do not all have the same views about migration. Haubert and Fussell (2006:492) argued that the Australian society is also divided with regards to migration policy, where the cosmopolitan population is more tolerant about immigration than the rest of the population living in other area. Education plays a crucial role in the attitude of Australians towards immigration. Similarly, Bruce-Briggs (2006:49) pointed out that those people with college education, trained in humanities and other social sciences and employed at universities and in the public sector, are more supportive of Australia's open immigration policy.

Serrie (1998:218) focused on the immigration policies of the United States and on the critical issues in the debate on reform of these policies. He regretted that the United States still prioritises the family reunification policy, but questioned immigration levels in terms of America's capacity to absorb the ever-increasing numbers of immigrants with respect to socio-cultural comfort and job competition.

Cross (2006:4) maintained that South Africa is creating barriers to migrants by holding jobs open solely for South Africans, who are often not available to fill the positions, while overseas competitors are dominating the market share. South Africa should open up a little to migration and go further towards creating a more flexible labour market in which migrants can be employed to the general benefit of the country. In South Africa, immigration should be used as a way to try and meet the challenges of international industrial and commercial competition as fast as possible to avoid deterioration in the country's economy (Cross, 2006:5). The only internationally recognised way to fill skills gaps quickly is through migration. It is regarded as a way of filling jobs that the citizens do not want to do, but in South Africa, it is about filling important positions that South Africans are not qualified to fill. South Africa is creating an unfavourable and unnecessary situation by making it hard for migrants to immigrate legally, and there is a tendency to reserve jobs for South African citizens, while there are not enough qualified South Africans to take them. This is restricting the country's economic growth and inhibiting job creation (Cross 2006:6).

\subsection{Divergence around migrants' origin and other qualification criteria}

Another debate concerns the diversity of source countries: European immigration to the United States has dropped to less that $10 \%$, which raises concerns of whether the country will only receive migrants from other parts of the world except the Europeans. Serrie (1998:219) further characterises as "illogic" the attempt to solve some of America's crisis regarding inadequately educated and trained native-born workers by increasing the number of visas related to employment and importing better educated and trained workers from abroad.

At the same time, Serrie (1998:219) qualified as "paradoxical" the attempt to solve America's crisis concerning native workers who are too highly paid to compete in the world economy by allowing large numbers of inadequately educated or trained foreign workers to enter the country and take jobs for minimum wages.

It is short-sighted to believe that the United States is capable of solving the problems of overpopulation and resulting poverty in the developing world by leaving the door wide open to legal and illegal immigrants as if everyone will be able to become affluent once they have arrived in the United States (Serrie, 1998:219). Serrie used the improbable example of China, where, if its population was proportionally divided among all the nations of the world, each nation would have a Chinese minority group totalling $24 \%$ of its population. Similarly, Serrie argued that if all Chinese were to be relocated to the United States, the country's physical environment would be $550 \%$ more crowded.

Sharry (2000:16) opposed the view that the United States government should increase the number of skilled immigrants by reducing the number of immigrants admitted on the basis of family reunification. His argument is that people should recognise the contribution that immigrants of all levels make to the America's extraordinary prosperity. His recommendation is that Congress should liberalise the immigration of all categories to sustain the achieved prosperity.

\subsection{Need for contingency funds}

According to the U.S. Urban Institute (2005:7), the composition of the child population in the United States is being affected, as 1 child in 5 (and 1 in 4 of low-income children) has an immigrant parent. This raises concern because many immigrants are low-income earners and without benefits; therefore, their children are in greater jeopardy with regards to poverty, economic hardship, and lack of access to health insurance, public benefits, child care and other needed services. Another crucial issue is that of distinguishing citizens from non-citizens, legal from undocumented immigrants, 
and refugees from other immigrants. Clarifying these distinctions involves analysis of the impacts of public policy on immigrants' families (The U.S. Urban Institute, 2005:7).

The way immigrants cross the borders constitutes also a topic of hot discussion between departure and destination countries. Given the number of immigrants who cross the Mediterranean Sea from Libya to Italy, there is an unsuccessful debate between these two countries about how to counter the movement. Laura Boldrini, the UN commissioner for Refugees, reports that the crossings are becoming more frequent and more dangerous, with people inexperienced in such ventures (Africatime.com, 2006:2).

\subsection{Consequences of migration}

Migration can have an important impact on both the supplying and the receiving regions. More often, immigration and emigration change the composition of age, sex ratios, literacy rates and demography of the affected areas. Furthermore, migration of people is useful for many reasons--both public and private: determination of population change in an area, together with vital statistics such as the number of people born and deceased in the area over a specific period of time, such as a year. Migration is important also because of the change in the makeup or composition of the communities involved (Goetz 1999:4).

On the other hand, migration can also be the cause of socio-political and economic problems. Once arrived in the country of destination, immigrants become a big burden to the government; they need financial assistance, accommodation, schooling for their children and other services. Africatime.com (2006:2) quoted the words of the Italian minister of transport who, after noting the problem of migrants crossing the Mediterranean Sea, decided to call on his government to provide 10 million Euros to reinforce the patrol of the sea.

Secondly, city, regional and rural planners need to be aware of the constant change in population over time to plan for the supply of the public infrastructure and services, planning for adequate school facilities, to avoid oversupply or undersupply (Goetz, 1999:6). Migration decisions have aggregate implications for the average level of income both in the destination and the origination community. Cromartie and Nord (cited by Goetz, 1999:8) reported that during the post1990 rural population growth spurt in the United States, the higher income of immigrants compared to emigrants increased overall rural per capita income by an estimated $\$ 30$ per year and migration increased per capita income in roughly half of all non-metropolitan areas.

\subsubsection{Advantages of migration}

The collective decisions of people to migrate have some effect on the communities of both places, those from where they come and the places to which they move. Cross (2006:6) reported that in South Africa, there is a fear of job losses and crime increase because of migration but maintained that if migration is managed properly and correctly, it may have a positive impact, especially on skills shortage, which is a big obstacle for the growth of the South African economy.

Immigration is an asset rather than a liability in Lesotho because it creates jobs, brings in skills, and increases the country's international profile and competitiveness (Akokpari, 2005:11). In the same vein, Gilbert and Koser (2006:201) claimed that immigration is important because of its role in helping to influence public opinion and government policy.

\subsubsection{Advantages to the host (receiving) communities or areas}

International migrants want to work hard and they are selected from highly educated groups from their countries of origin. Those who are coming into South Africa are helping to some degree to reduce the skills gap, even if not enough. In Southern Africa, there is no tradition of teaching young children to become entrepreneurs from a young age, as happens in Western Africa. Therefore, West African migrants bring these skills with them, and when they employ South Africans, they pass on the skills that are missing in indigenous cultural behaviours (Cross, 2006:7). Small businesses in the informal category, where mentoring by migrants is intense, seem to provide the most effective, far-reaching and quickest skills-training programmes (Cross, 2006:7).

In receiving areas, some people can benefit from migration and undergo some training to assist in dealing with immigrants. According to SA info. reporter (2004:43), in 2002 and 2003, the United Nations High Commission for Refugees (UNHCR) trained 40 lawyers to assist the South African Department of Home Affairs to clear immigrants' cases. However, the number of cases piled up again after many of the lawyers left to find more lucrative jobs. In 2004, 
there were some 52000 cases awaiting status determination in South Africa ${ }^{1}$.

Perbedy and Crush's (1998: 2) study was focused on handicraft and curio traders. In their interviews with 107 nonSouth Africans and 21 South Africans, they discovered that more than 1 in 5 non-South African traders employ South Africans. All these employees are identified as women.

In contrast to the poor people in receiving areas, who become poorer, merchants and shopkeepers in the receiving areas that are becoming booming communities may become wealthy, at least in the short term, because they happen to be in the right place at the right time (Cross, 2006:6). Highlighting the population growth of some US states, such as Nevada (39.5\% from 1990 to 1997) and Utah (19.5\% between 1990 and 1997), Goetz (1999:6-7) maintained that immigrants create many opportunities for local business and also stimulate the growth of new businesses because of the rapid population growth.

Haubert and Fussell (2006: 493) confirmed that business owners and managers may benefit from immigrants' labour because, "immigrants with fewer skills or limited English proficiency are typically willing to work for lower wages than the native-born." According to US Urban Institute (2005), immigrants contribute greatly to the economy and tax of the Washington D.C. region. More than a million immigrants from various countries represent $19 \%$ of the region's total household income and $18 \%$ of all taxes paid.

Immigration can help governments to shape their business and administrative policies. As reported by Jonathan (1995:18), the Canadian standards of living after 1995 depended greatly on its export performance. The Canadian government kept this in mind when trying to attain an ambitious goal of doubling the number of exporters from 1995-2000 and increasing the export levels of firms already existing. One of the three sources exporters took advantage of was the enhancement of immigration-based export.

\subsubsection{Disadvantages of migration}

Compromising jobs, increasing crimes, spreading of diseases and undermining the homogeneity of his country, Lesotho, are the negative points of immigration, according to Akokpari (2005:11). Negative behaviour towards immigrants has its roots in the fact that the native-born group perceives immigrants as social and economic threats to the locals (Haubert \& Fussell, 2006:493). Studies conducted in Canada, the UK, the USA, Germany, and France have all reached the same conclusions--that the native-born perceive immigrants as a crime threat (Palmer, 1996), an economic threat (Scheve \& Slaughter, 2001; Fetzer, 2000; Simon \& Lynch 1999; Palmer, 1996; Quillian, 1995; Simon, 1993), or a cultural threat (Chandler \& Tsai, 2001; Espenshade \& Hemstead, 1996; Espenshade \& Calhoun, 1993). When current events or a given social position make these threats more salient, an individual is more likely to view immigrants negatively.

With regard to South Africa, people argue that, in some instances, the increase in the number of immigrants has generated tensions with South African citizens, blaming certain refugees and illegal immigrants for escalating crime. Xenophobia has thus become an issue in some areas (SA info. reporter, 2004:3).

Labour market competition is another area where immigrants are regarded as threats to the dominance of the native-born. Immigrants enter into competition with locals with low skills and can be an alternative for employers wanting to hire lower-salaried employees. More importantly, the blue-collar and service workers are most threatened by competition from low-skill immigrants, while white-collar workers are not in direct competition with immigrants (Haubert \& Fussell, 2006:493).

\subsubsection{Disadvantages to the host (receiving) communities}

Economic costs can follow the congestion and may escalate rapidly in the communities receiving a large number of immigrants. Property values can rise quickly and become unaffordable for the existing communities as wealthy immigrants can cope with the rise and move out of suburbs and back into the cities. More often, long-term residents with limited or fixed incomes find property values and tax burdens rise quickly and become unaffordable to them; this is called "gentrification" (Goetz, 1999:6). An illustrative case occurs in rural areas located at the periphery of urban areas, where wealthy people, attracted by the rural amenities, drive up land and housing costs with the objective of pushing low-income families further into remote areas, which then become enclaves of the poor (Goetz,1999:6).

With immigration, problems can arise when newcomers demand more services, or new services, than are available, especially if they have some socio-economic characteristics that are different from those of the resident

\footnotetext{
${ }^{1}$ The attempt by the researcher to establish the current state on the issue from the Refugee Status Determination Standing Committee was unsuccessful.
} 
population, such as smaller children needing the construction of more schools, a demand to provide extra socio-medical services, the need for churches other than those representing the resident population, and other demands (Cross, 2006:8).

There is, in South Africa, a problem of not being able to quantify and recognise the role of immigrants' skills in the economy, the reason being that some at lower levels of work may be undocumented workers who use false South African identification. Also, in South Africa, the small businesses run by poor South Africans are suffering from strong competition from foreigners who seem to be more skilled and better educated and financially supported (Cross, 2006:9).

\subsubsection{Disadvantages to the immigrants' communities}

There are some differences between locals and foreign traders, and foreigners complain that they are never granted business sites in central business districts. They use private markets, which cost more money to rent than the government-controlled sites, which results in greater police harassment than that experienced by locals (Hunter \& Skinner, 2001:22).

Immigrant doctors, engineers and teachers have managed to find employment and their children's education has improved at primary level. However, it is much harder at secondary and tertiary levels (SA info. reporter, 2004:3).

\section{Methodology}

\subsection{Research approach}

The current study used mixed methods approach. In the view of Johnson, Onwuegbuzie and Turner (2007:119), a mixed methods study is one that deliberately juxtaposes or brings together methods of different types (qualitative and quantitative) so that a more detailed understanding of the phenomenon under study (including its context) can be provided.

Descriptive study explains traits, people, groups, organisations or environments (Zikmund, Babin, Carr and Griffin (2010:55). Therefore, descriptive study tries to address who, what, when, where and how questions. This study used descriptive research as the main question was how the entrepreneurial skills takes place from immigrants entrepreneurs to local South Africans.

\subsection{Research instrument}

The methodology used to carry out the study was a survey by means of questionnaires. Two semi-structured sets of questions were developed, one for African immigrant entrepreneurs and the other for immigrant-support organisations. Both questionnaires were pilot-tested to ensure clarity, comprehension and ease of use. These instruments were utilised for collecting data measuring the respondents' characteristics, the types of businesses they run, the choice of business locations as well as the businesses with high turnovers.

A set of questions to the immigrant entrepreneurs to measure the transmission of entrepreneurial skills from foreigners to locals was included in the questionnaire. At the same time, a set of questions to the South African employees to measure the level of entrepreneurial skills transmission was included in the questionnaire. The questionnaire to seven organisations which offer services, advice and support for immigrants in Cape Town provided data on the profile of the organisations, their interaction with immigrants and the support and training they provide for the immigrants.

\subsection{Validity and reliability}

As put by Zikmund et al. (2010:307), content validity refers to the degree that a measure covers the domain of interest. Content validity was maintained by as the instrument and interviews were aimed at only achieving the objectives of the study and nothing more. Criterion validity refers to the ability of the measure to correlate with other standard measures of similar constructs or established criteria. The current study relied on similar researches about the positive impact of immigrants on local South Africans, and since the sample was drawn from a diverse of origins of immigrants from African continent, criterion validity is maintained. Furthermore, to ensure clarity, correct wording and comprehension of instructions, as well as the easy use of the questionnaire, a pilot study was run, thereby maintaining construct validity. 


\subsection{Data collection}

Data from African immigrant entrepreneurs were collected by means of personal visits and face-to-face interviews between data collectors and the respondents. The respondents participated with their own consent, and safe, confidential environments were chosen for the interviews. Data from immigrant-support organisations were collected electronically (that is by fax and e-mail).

\subsection{Population}

The target population of this study was a group of African immigrant entrepreneurs who operate in the suburbs of Bellville, the Cape Town CBD, Nyanga and Wynberg. These sites were chosen for their heavy immigrant entrepreneur presence.

Dorsten and Hotchkiss (2005:28) posit that a population should be defined to include individuals we want to describe, not just those who return the questionnaire. For the purpose of this study, the targeted population was a group of African foreign entrepreneurs who:

- Run their businesses in Cape Town and some surrounding suburbs

- Employ South Africans in their businesses

As pointed by Zikmund et al (2010:119), the unit of analysis for a study indicates what or who should provide the data and at what level of aggregation. Hence, African foreign entrepreneurs who run their businesses in Cape Town are the unit of analysis as they provided required and relevant responses for the study.

\subsection{Sample and sampling technique}

The sample was comprised of 120 African immigrants who run their businesses in certain suburbs of Cape Town. The selection criteria for the respondents involved the employment preferences an African immigrant entrepreneur. In other words, any African immigrant entrepreneur operating in the abovementioned suburbs who employs any number of locals was considered to be a participant in the study, while an African immigrant entrepreneur who employs only immigrants was not considered suitable to participate in the study. The sampling method used in the research was convenience sampling, which is a type of non-probability sampling. Non-probability sampling is advantageous in that it is less complicated and more economical in terms of time and financial expenses (Welman, Kruger and Mitchell (2005:68).

\subsection{Data presentation and analysis}

The collected data were presented in a tabular format, while analysis was done by categorising questions according to the research objectives. Where the questions were similar in both questionnaires, the responses were compared in tabular form, which allowed a better interpretation of the results.

\section{Findings of the empirical study}

The results of the study were discussed in accordance with the objectives and questions formulated for the research, that is, to ascertain whether African immigrant entrepreneurs transmit their entrepreneurial skills to local individuals. Below are the subheadings under which they are presented:

- The characteristics of the respondents

- Business activities African immigrant entrepreneurs are involved in

- The selection of the business locations

- The identification of business activities with high turnovers

- Immigrants' entrepreneurial skills transmission to locals.

Table 1 below illustrates the characteristics of the respondents, as collected from African immigrant entrepreneurs. 
Table 1: Biographical information

\begin{tabular}{|c|c|c|c|c|c|c|c|c|c|c|c|}
\hline \multirow{3}{*}{ Variables } & \multirow{3}{*}{ Description } & \multicolumn{8}{|c|}{ Origin of African immigrants entrepreneurs } & & \\
\hline & & \multicolumn{2}{|c|}{ Nigeria } & \multicolumn{2}{|c|}{$\begin{array}{c}\text { Somalia } \\
N=40\end{array}$} & \multicolumn{2}{|c|}{$\begin{array}{c}\text { Senegal } \\
N=40\end{array}$} & \multicolumn{2}{|c|}{$\begin{array}{c}\text { Other* } \\
N=20\end{array}$} & \multicolumn{2}{|c|}{$\begin{array}{c}\text { Total } \\
\mathrm{N}=120\end{array}$} \\
\hline & & $\mathrm{F}$ & $\%$ & $\mathrm{~F}$ & $\%$ & $\mathrm{~F}$ & $\%$ & $\mathrm{~F}$ & $\%$ & $\mathrm{~F}$ & $\%$ \\
\hline \multirow{2}{*}{ Gender } & Male & 38 & 95 & 40 & 100 & 19 & 95 & 19 & 95 & 116 & 97 \\
\hline & Female & 2 & 5 & 0 & 0 & 1 & 5 & 1 & 5 & 4 & 3 \\
\hline \multirow{4}{*}{ Age } & $<20$ & 0 & 0 & 8 & 20 & 1 & 5 & 0 & 0 & 9 & 8 \\
\hline & $21-30$ & 12 & 30 & 23 & 58 & 7 & 35 & 8 & 40 & 50 & 42 \\
\hline & $31-40$ & 24 & 60 & 9 & 23 & 12 & 60 & 12 & 60 & 57 & 47 \\
\hline & $>40$ & 4 & 10 & 0 & 0 & 0 & 0 & 0 & 0 & 4 & 3 \\
\hline \multirow[t]{5}{*}{ Education } & Primary & 2 & 5 & 22 & 55 & 0 & 0 & 0 & 0 & 24 & 20 \\
\hline & High & 21 & 53 & 16 & 40 & 15 & 75 & 7 & 35 & 59 & 49 \\
\hline & College & 9 & 23 & 2 & 5 & 5 & 25 & 3 & 15 & 19 & 16 \\
\hline & Tertiary u/g & 4 & 10 & 0 & 0 & 0 & 0 & 7 & 35 & 11 & 9 \\
\hline & Tertiary $\mathrm{p} / \mathrm{g}$ & 4 & 10 & 0 & 0 & 0 & 0 & 3 & 15 & 7 & 6 \\
\hline \multirow[t]{4}{*}{ Duration of stay in RSA** } & $<5$ years & 18 & 45 & 19 & 48 & 8 & 40 & 8 & 40 & 53 & 45 \\
\hline & 5-10 years & 15 & 38 & 16 & 40 & 9 & 45 & 7 & 35 & 47 & 40 \\
\hline & $11-15$ years & 7 & 18 & 3 & 8 & 3 & 15 & 5 & 25 & 18 & 15 \\
\hline & $>15$ years & 0 & 0 & 0 & 0 & 0 & 0 & 0 & 0 & 0 & 0 \\
\hline \multicolumn{12}{|c|}{$\mathrm{N}=$ Number of respondents F: Frequency } \\
\hline
\end{tabular}

\subsection{Respondents' characteristics}

The gender of the respondents who participated in the survey was mostly male (97\%) with a low participative rate from females (3\%). A number of factors contribute to this gender imbalance:

- African males are more open to the venture than females

- With an uncertain future when they decide to leave their home countries, male economic migrants prefer to take an individual risk rather than being with their families

- Traditionally, African males are more involved in activities that financially support their families, while females are more involved in household activities.

This finding also correlates with the findings of Rogerson's (1999:5) study, that is, that immigrants' businesses are run by single, young male entrepreneurs, who work long hours, often 64 per week, 6 days a week, and if they have employees, they also work similar hours.

The age group of $31-40$ is the most involved in businesses, representing $47 \%$, followed by the age group of 21-30, representing $42 \%$. This finding is linked to the fact that $21-30$ is the period of activity for many young people who complete high school, and if they do not further their studies, they either open their own small businesses or are employed in the existing businesses. With regards to the level of education of the respondents, the majority of the respondents from Somalia have only completed primary school. This is not a surprise. As pointed out by Marriot (2008:108), Somalia is today a nation wrecked by internal conflict; the consequence of prolonged clan warfare and a power struggle between an Islamic movement and an interim government composed of former warlords. The lack of central administration has led to millions living in severe poverty and a virtual standstill in health care and education.

Table 2 illustrates the variety of businesses in which African immigrant entrepreneurs are involved, whether as retailers or service providers. 
Table 2: Businesses in which African immigrant entrepreneurs are involved

\begin{tabular}{|c|c|c|c|c|c|c|c|c|c|c|}
\hline \multirow{3}{*}{ Businesses: Retail/service } & \multicolumn{8}{|c|}{ Origin of African immigrant entrepreneurs } & & \\
\hline & \multicolumn{2}{|c|}{$\begin{array}{c}\text { Nigeria } \\
N=40\end{array}$} & \multicolumn{2}{|c|}{$\begin{array}{c}\text { Somalia } \\
N=40\end{array}$} & \multicolumn{2}{|c|}{$\begin{array}{c}\text { Senegal } \\
N=20\end{array}$} & \multicolumn{2}{|c|}{$\begin{array}{l}\text { Other* } \\
N=20\end{array}$} & \multicolumn{2}{|c|}{$\begin{array}{c}\text { Total } \\
\mathrm{N}=120\end{array}$} \\
\hline & $\mathbf{F}$ & $\%$ & $\mathbf{F}$ & $\%$ & $\mathbf{F}$ & $\%$ & $\mathbf{F}$ & $\%$ & $\mathbf{F}$ & $\%$ \\
\hline Clothing & 13 & 33 & 19 & 48 & 6 & 30 & 4 & 20 & 42 & 35 \\
\hline Footwear & 8 & 20 & 5 & 13 & 8 & 40 & 2 & 10 & 23 & 19 \\
\hline Groceries & 2 & 5 & 11 & 28 & 2 & 10 & 2 & 10 & 17 & 14 \\
\hline Bags, caps and belts & 6 & 15 & 0 & 0 & 3 & 15 & 2 & 10 & 11 & 9 \\
\hline Restaurant & 2 & 5 & 1 & 3 & 1 & 5 & 1 & 5 & 5 & 4 \\
\hline Hairdressing & 3 & 8 & 0 & 0 & 0 & 0 & 2 & 10 & 5 & 4 \\
\hline Second hand goods & 2 & 5 & 0 & 0 & 0 & 0 & 4 & 20 & 6 & 5 \\
\hline Others ${ }^{\star *}$ & 4 & 10 & 4 & 10 & 0 & 0 & 4 & 15 & 12 & 10 \\
\hline Total & 40 & 100 & 40 & 100 & 20 & 100 & 20 & 100 & 120 & 100 \\
\hline
\end{tabular}

* The group designated as "other" comprises Cameroon (6), Tanzania (5), Angola (4), Zimbabwe (2), Rwanda (2) and Morocco (1).

**The group designated as "others" comprises businesses such jewellery, panel beating, traditional healing, spices, music/movie shops, etc.

\subsection{Businesses African immigrant entrepreneurs are involved in.}

African immigrants in Cape Town are involved in a wide range of activities. Some of these activities require a relatively big investment, while others require less. The study has shown that $35 \%$ of African immigrant entrepreneurs are involved in the clothing trade. This finding may be compared to the research done by Peberdy (2000:14), who found that textiles products are sold predominantly by South African-Mozambique border-crossing entrepreneurs who travel every day to sell their products on the other side of the border. As highlighted by African immigrant entrepreneurs in Cape Town, the reason for this high involvement in the clothing sector is that South Africa seems to be a fashion-driven society, where people are aware and very sensitive to the new product reaching the market and the seller can make money out of such behaviour. Secondly, clothing products are easy to store. With a common storage for all the people who sell similar products, no one is aware of how the latecomers will handle the storage so that there is no damage to the products. If the handling was not careful, there will be no damage to the clothes, unlike the case of other products that require a high level of care such as watches, crockery, and products in the grocery sector.

Furthermore, African immigrant entrepreneurs are more involved in the clothing sector because some of them are targeting their fellow immigrants by providing the kinds of clothes similar to those they are used to in their home countries. These are involved in ethnic clothing products. Somalis have a higher involvement in clothing sector than any other nationality and providing clothes to their fellow women from Somalia whose mode of dressing is far different from other Cape Town residents. This finding can be compared to the finding from Rogerson (1999:6) who confirms that within the group of production SMMEs, many immigrants are clustered in the clothing sector where they are involved in the making of traditional African clothes, wedding dresses, and general tailoring activities. The presence of Somalis involved in clothing sector in the suburb of Bellville is much felt and today some of them are operating as wholesalers.

Another point that is worth mentioning here is that most of the people who run the businesses are not in South Africa for more than 5 years, but considering the size of many of the businesses, one cannot help but wonder how they manage to grow the business to that level in such a short period. The response to a question posed to the interviewed immigrant entrepreneurs about this was that businesses are run as partnerships composed of more than five members in most cases. With regards to footwear, the respondents mentioned that they provide quality shoes at low cost and this allows them to be sustainable in the highly competitive environment. Selling shoes does not require sophisticated equipment, such as quality shelves, as most of immigrants display the shoes on the top of the boxes and generally combine selling shoes with something else, such as bags and belts.

A number of African immigrants are involved in restaurants. Some of the restaurants visited by the researcher, such as the Madiba Restaurant in Bellville, run by Somalis, and Amon's restaurant in Cape Town, run by a Nigerian, have a competitive advantage because they provide a large variety of food, are inexpensive, and serve high quality food. The Madiba restaurant provides a wide range of local food, such as chicken, rice, spaghetti, meat, salad, and so on, as well as catering for the Somalis with the preferred food of their home country, such as maize bread, sweet potatoes and 
others.

In the past few years, Somali refugee entrepreneurs in South Africa have had confrontations with some locals, and civil authorities have had to intervene to request the people to stop the violence. Most comments were linked to the jealousy of locals as these Somalis entrepreneurs run successful businesses. According to Benton (2007:2) the then Western Cape Premier, Ebrahim Rasool (currently South African ambassador to the United States of America) told the crowd at Masiphumele, in southern Cape Town that locals could learn from some "Somalis as they went about earning an independent livelihood through their trading stores". At the same time, Rasool said that "Somalis could learn lessons from South Africans in terms of a growing culture of human rights that ensures equality between all people, including across the gender divide".

These findings can be compared with the study done by Rogerson (1999:6), who ascertained that foreign-owned SMMEs are now a significant element of the changing economy and landscape of the Johannesburg inner-city, and therefore, the following conclusions can be drawn about foreign migrant involvement in the SMME sector:

- Immigrant entrepreneurs in South Africa are visible in a narrow band of activities of SMMEs, mostly in retail or service rather than production activities. Their activities involve selling curios, retailing ethnic clothes and foods, motor-car repairs/panel beating, and hairdressing salons. Other activities include operation of restaurants, nightclubs, cafes, music shops, several import-export businesses and practising as traditional healers.

- Immigrant entrepreneurs show distinct trends in the kinds of businesses they run. Malawian immigrants tend to concentrate on clothes production or curio selling, while Mozambicans and Zimbabweans are more visible in motor-car repair and curio-selling activities. West Africans are mainly in ethnic businesses related to clothes, food retailing and operation of restaurants.

Table 3 illustrates the level of African immigrant entrepreneurs' preferences in choosing locations for their businesses.

Table 3: Selection of business locations

\begin{tabular}{|c|c|c|c|c|c|c|c|c|c|c|}
\hline \multirow{3}{*}{ Business locations } & \multicolumn{8}{|c|}{ Origin of immigrant entrepreneurs } & & \\
\hline & \multicolumn{2}{|c|}{$\begin{array}{c}\text { Nigeria } \\
\mathrm{N}=40\end{array}$} & \multicolumn{2}{|c|}{$\begin{array}{c}\text { Somalia } \\
N=40\end{array}$} & \multicolumn{2}{|c|}{$\begin{array}{c}\text { Senegal } \\
N=20\end{array}$} & \multicolumn{2}{|c|}{$\begin{array}{c}\text { Other* }_{\mathrm{N}=20}\end{array}$} & \multicolumn{2}{|c|}{$\begin{array}{c}\text { Total } \\
\mathrm{N}=120\end{array}$} \\
\hline & $\mathbf{F}$ & $\%$ & $\mathbf{F}$ & $\%$ & $F$ & $\%$ & $F$ & $\%$ & $F$ & $\%$ \\
\hline Big suburbs & 21 & 53 & 14 & 35 & 12 & 60 & 6 & 30 & 47 & 39 \\
\hline Town centre & 16 & 40 & 7 & 17 & 3 & 15 & 7 & 35 & 37 & 31 \\
\hline Townships & 3 & 7 & 19 & 48 & 5 & 25 & 7 & 35 & 36 & 30 \\
\hline Total & 40 & 100 & 40 & 100 & 20 & 100 & 20 & 100 & 120 & 100 \\
\hline
\end{tabular}

* The group designated as "other" comprises Cameroon (6), Tanzania (5), Angola (4), Zimbabwe (2), Rwanda (2) and Morocco (1).

\subsection{Selection of business locations}

The selection of business location is not an easy process for immigrant entrepreneurs as they are considered as a threat in some areas of South Africa. Consequently, many of them take the necessary measures before deciding to open up their businesses. In addition to this, competition is also very fierce among foreigners of different nationalities, or between foreigners of the same nationality. In the suburb of Bellville (Cape Town), Somalis have heavily invested in the clothing and grocery sectors, occupying almost every building and applying price-predator techniques to drive other competitors out of business. Once the next place is available, as a result of the inability of local people to cope with Somali competition, Somalis immediately occupy it and extend their businesses and operate as wholesalers or retailers, depending on the size of the place. This heavy presence in the suburb raises some concerns whether it will not lead to some misunderstandings and confrontations with locals as it happened in some other small towns of the Western Cape and Eastern Cape provinces where some locals have attacked Somalis' shops, looting, setting some alight, wounding the owners, and even killing some of them.

The element of competition was also highlighted by Cross (2006:7) who reported that small businesses run by poor South Africans are suffering from strong competition from foreigners who seem to be more skilled, better educated and better financially supported. However, one needs to inquire about the financial support mentioned by Cross because 
none of the immigrants I managed to speak to confirmed receiving any financial support either in starting up or sustaining their businesses.

Of the immigrant entrepreneurs who participated in the study, 39\% confirmed that they prefer to run their businesses in big suburbs rather than in town centres because of the rental of the premises, which is higher in the CBD. As a result, they spend a big portion of their profit in paying rent. Big suburbs are also preferred as they present the advantage of being in a strategic location and are visited by a large number of people, from all areas of Cape Town, not as tourists, but as buyers, especially for products such as cloths, jewellery, shoes, and so on.

A good percentage (31\%) prefer to run their businesses in a town centre, and as confirmed by Onajefe, a Nigerian immigrant entrepreneur, running a business in the town centre is the best, given the constant presence of customers throughout the day. "Even tourists come and buy our products, and there are many in the town centre", said Onajefe. Sadly, as confirmed by Casey, another Nigerian immigrant entrepreneur who operates in the taxi rank in Cape Town, in October 2007, 80 foreign immigrant entrepreneurs, who were operating in the city centre, next to the Cape Town taxi rank, were forced to close down their businesses without any notice and without any reason. This confirms what Rogerson (1999:6) found--that these immigrant entrepreneurs face a number of problems and endure considerable hostility towards themselves and their businesses as a result of xenophobia.

For immigrant entrepreneurs, the selection of business locations in townships was very strategic, given the high concentration of people who eventually become the customers of the business. Most of these business activities in townships involve convenience products such as sweets, bread, milk, cigarettes, chocolates, soaps, airtimes, and so on. However, setting up business has become risky and dangerous because of the frustration and "xenophobia" of locals. Despite those conditions, $30 \%$ of those immigrant entrepreneurs interviewed still run their businesses in townships but with sentiments of fear. They are just extremely cautious in the way they deal with young and unemployed males in their surroundings.

As mentioned by Rogerson (1999:8), despite those difficult local conditions in which immigrants operate, most of them express their optimism and look to the possibilities of expanding their businesses outside Johannesburg in South Africa. They do not have access to finances and credit, encounter problems in opening bank accounts, have difficulty acquiring visas and permits and dealing with customs, are often harassed by police and local officials, and are targeted by criminals and gangs.

Table 4 illustrates the African immigrants' opinions concerning businesses that can generate quick and high turnovers.

Table 4: African immigrant activities with high turnovers

\begin{tabular}{|c|c|c|c|c|c|c|c|c|c|c|}
\hline \multirow{3}{*}{ Businesses } & \multicolumn{8}{|c|}{ Origin of African immigrant entrepreneurs } & & \\
\hline & \multicolumn{2}{|c|}{$\begin{array}{c}\begin{array}{c}\text { Nigeria } \\
\mathrm{N}=40\end{array}\end{array}$} & \multicolumn{2}{|c|}{$\begin{array}{c}\text { Somalia } \\
N=40\end{array}$} & \multicolumn{2}{|c|}{$\begin{array}{c}\text { Senegal } \\
N=20\end{array}$} & \multicolumn{2}{|c|}{$\begin{array}{l}\text { Other* } \\
N=20\end{array}$} & \multicolumn{2}{|c|}{$\begin{array}{c}\text { Total } \\
\mathrm{N}=120\end{array}$} \\
\hline & $\mathbf{F}$ & $\%$ & $\mathbf{F}$ & $\%$ & $\mathbf{F}$ & $\%$ & $\mathbf{F}$ & $\%$ & $\mathbf{F}$ & $\%$ \\
\hline Restaurant & 17 & 43 & 15 & 38 & 10 & 50 & 7 & 35 & 49 & 41 \\
\hline Groceries & 10 & 25 & 10 & 25 & 5 & 25 & 6 & 30 & 31 & 26 \\
\hline Clothing & 8 & 20 & 12 & 30 & 4 & 20 & 6 & 30 & 30 & 25 \\
\hline Footwear & 5 & 12 & 3 & 7 & 1 & 5 & 1 & 5 & 10 & 8 \\
\hline Total & 40 & 100 & 40 & 100 & 20 & 100 & 20 & 100 & 120 & 100 \\
\hline
\end{tabular}

* The group designated as "other" comprises Cameroon (6), Tanzania (5), Angola (4), Zimbabwe (2), Rwanda (2) and Morocco (1).

**The group designated as "others" comprises businesses such jewellery, panel beating, traditional healing, spices, music/movie shops, etc.

\subsection{African immigrants' business activities with quicker and higher turnovers}

The research study was focused on activities with quick and high turnovers, thereby creating more chances of employment for locals. With an unemployment rate of $25.5 \%$, job creation remains a big challenge for the South African government. Although the South African economy has shown a positive trend for more than a decade, the public as well as the private sector are still unable to employ all South Africans who are in need of employment. Of the respondents, $41 \%$ believed that a restaurant provides better and quicker turnovers than the other types of the businesses immigrants are involved in. A further $26 \%$ had chosen the grocery business, while $25 \%$ were in the clothing business. The gap 
between these three figures is not very great, particularly between groceries and clothing, which proves a high level of understanding of the business sector. Furthermore, this finding drew attention to the fact that immigrant entrepreneurs possess information concerning businesses other than those they are involved in. For instance, though an immigrant entrepreneur is selling shoes, he is aware that a restaurant would be the best opportunity as far as quick and high turnover is concerned.

Immigrant entrepreneurs explained their involvement in the restaurant business by pointing out that the growing number of metropolitan residents increases the need to provide more diversified and affordable types of food. By involvement in this business, immigrant entrepreneurs target their compatriots and provide a kind of food similar to that they are used to eating in their home countries at a low cost. Therefore, they know they will secure a big clientele, consequently requiring them to employ many more people, including South Africans, to accomplish various activities inside and outside the restaurant.

Table 5 illustrates the level of entrepreneurial skills transmission from African immigrant entrepreneurs to locals.

Table 5: Transmission of entrepreneurial skills

\begin{tabular}{|c|c|c|c|c|c|c|c|c|c|c|}
\hline \multirow{3}{*}{ Businesses } & \multicolumn{8}{|c|}{ Origin of African immigrant entrepreneurs } & & \\
\hline & \multicolumn{2}{|c|}{$\begin{array}{c}\text { Nigeria } \\
\mathrm{N}=40\end{array}$} & \multicolumn{2}{|c|}{$\begin{array}{c}\text { Somalia } \\
N=40\end{array}$} & \multicolumn{2}{|c|}{$\begin{array}{c}\text { Senegal } \\
\mathrm{N}=20\end{array}$} & \multicolumn{2}{|c|}{$\begin{array}{l}\text { Other* } \\
\mathrm{N}=20\end{array}$} & \multicolumn{2}{|c|}{$\begin{array}{c}\text { Total } \\
\mathrm{N}=120\end{array}$} \\
\hline & $\mathbf{F}$ & $\%$ & $\mathbf{F}$ & $\%$ & $\mathbf{F}$ & $\%$ & $\mathbf{F}$ & $\%$ & $\mathbf{F}$ & $\%$ \\
\hline Training \& teaching & 17 & 43 & 16 & 40 & 9 & 45 & 8 & 40 & 50 & 42 \\
\hline Experience & 13 & 32 & 12 & 30 & 7 & 35 & 8 & 40 & 40 & 33 \\
\hline Imitation & 10 & 25 & 12 & 30 & 4 & 20 & 4 & 20 & 30 & 25 \\
\hline Total & 40 & 100 & 40 & 100 & 20 & 100 & 20 & 100 & 120 & 100 \\
\hline \multicolumn{11}{|c|}{$\mathrm{N}$ : Number of respondents F: Frequency } \\
\hline
\end{tabular}

\subsection{Transmission of entrepreneurial skills to locals}

The main finding reported in this section is that African immigrant entrepreneurs believe and confirm that there is a high level of entrepreneurial skills transmission to South Africans who work for them. At the same time, local employees also confirm that a transfer of entrepreneurial skills is taking place. Unanimously, the interviewed immigrant entrepreneurs agree that the skills transmission is done through training and teaching, experience, and imitation. On a Likert-type scale, ranging from very high to very low, African immigrant entrepreneurs showed (at 38\% and 35\%) that entrepreneurial skills transmission is taking place at a high and a very high level respectively. Each of the following variables was used to measure the skills transmission level from immigrants to locals:

- Training and/or teaching: $42 \%$ of African immigrant entrepreneurs are of the opinion that they transmit their entrepreneurial skills through training and/or teaching, because when they pick someone to work, they have to train and/or teach her/him how to do the job in case the employee lacks experience.

- Experience: $33 \%$ of interviewed African immigrant entrepreneurs believe that the acquisition of experience is another way through which they are helping their local employees to become entrepreneurs because after working for immigrants, some of these employees manage to open up their own businesses. This was confirmed by Casey, a Nigerian entrepreneur, who named three of his former employees who have opened their own businesses, which they are successfully operating in their suburbs.

- Imitation: $25 \%$ of interviewed immigrant entrepreneurs confirmed that imitation also helps their local employees and other South Africans to become self-employed because many South Africans realise that foreigners are successful in their businesses and try to emulate them.

To validate the employers' findings, local employees were also interviewed concerning their opinions about entrepreneurial skills transmission. The variables used to confirm the entrepreneurial skills transmission were training, experience, learning and imitation, and motivation to engage in entrepreneurial activity. Unanimously, they all agreed that they gained skills relating to starting and running a small business. Many of them helped their employers to answer the questionnaire, which confirms their knowledge of the state of the business as well a good relationship between employee and employer.

According to the employees, $32 \%$ of entrepreneurial skills acquisition is done through learning and imitation, while 
training and teaching from employer (African immigrant entrepreneur) scored $28 \%$ as a means of entrepreneurial skills acquisition. Experience scored 22\%, while commitment and motivation to entrepreneurial activity facilitates entrepreneurial skills acquisition from immigrant entrepreneur to local employee scored $18 \%$. This low level of entrepreneurial skills acquisition through commitment and motivation to entrepreneurship is due to the lack of entrepreneurial awareness in employees when they join the employment. Soon after realising the financial benefits of running one's own small business, they start moving into entrepreneurship.

The duration of employment between starting to work and eventually learning about business and moving into selfemployment after the acquisition of entrepreneurial skills varies from one employee to another. Those who are still in employment, but thinking of becoming self-employed, argue that they are still raising the capital, while others still need more experience. In fact, $73 \%$ consider becoming self-employed, of whom $83 \%$ confirmed they were waiting to have enough capital. The employees I managed to talk to outside the interview were amazed at how foreigners do not hesitate to take risks and decide to open a business next to the person who is selling the same products. "This is what we also need to do", they exclaimed.

The other finding concerning skills transmission was that African immigrant entrepreneurs expressed their willingness to share their entrepreneurial skills with locals, but some of them posed certain conditions on prospective employees, such as if they are also willing to learn or if they bring capital. Few of them, however, expressed the competition-related fear that if South Africans acquire skills, they will take over all the opportunities that the immigrants are exploiting, or that there will be an increase in competition, or the possibility of locals taking over the foreign-owned businesses. Those who are willing, unconditionally, to share their skills with locals have put forward the reasons of their choice as teaching them to take a risk, encouraging them to become involved in the economic life of the country, motivating them to undertake independent action and not to wait for everything from government.

At the same time, some immigrant entrepreneurs refer to as "insufficient"; the way government is educating people to become entrepreneurs. These shortages of entrepreneurship education as well as the lack of training were also highlighted by Orford, Wood, Fischer, Herrington and Segal (2003:17) as the main obstacles to entrepreneurship development. They put the lack of financial support in the second position and cultural and social norms in third position.

The skills transmission from African immigrant entrepreneurs to employees was also confirmed by the then Deputy Minister of Home Affairs Malusi Gigaba (currently Minister of Public Enterprises) on the occasion of celebrating Human Rights Day, 22 March 2007. He said, "South Africans need to realise that the country can benefit from the presence of immigrants and refugees, because many of them bring skills, including some of the scarce skills needed by the South African economy". He claimed that the "entrepreneurial spirit and culture" that many refugees bring can, "if properly harnessed", benefit local communities (Benton, 2007:2).

Finally, immigrant entrepreneurs offered advice to South Africans who try to open up their small businesses to commit to the learning process and to learn how to work together in order for them to cope with the competition. This will help them to enhance the skills learnt and to fully benefit from them.

\section{Conclusion and Recommendations}

Today, migration has become a defining issue, especially in countries that present many enticing factors, such as true democracy, where migrants find their human rights guaranteed and economic conditions that offer realities completely different from the immigrants' countries of origin. It is therefore suggested that governments should not spend time discussing how to counter migration but how to benefit from it. On the African continent, South Africa seems to be the only country where migrants can find both conditions met. Research into a number of aspects of immigrant entrepreneurship can hugely benefit the economies of host countries while contributing positively to the lives of their populations. In this paper, I have presented the consequences of migration in general, and reported particularly on research findings that reveal that South African society can benefit from accepting a large number of migrants. Concerning South Africa, it is recommended that the prospective change in immigration law takes into account the integration of immigrant entrepreneurs, given their contribution to skills development and economic growth. It is therefore recommended that further research be undertaken aiming at including immigrants in financial support systems, as well as a quicker process of their applications for refugee status or permanent residence. This research, it is hoped, will be of crucial importance in an environment where immigrant entrepreneurs face harassment and brutality directed at themselves and their businesses. Such a research will also benefit those organisations that assist in the development of micro and small enterprises and those who support immigrants. 


\section{References}

Africatime.com (2006). UN rebuke as governments squabble over immigrants found over clinging to tuna nets. [Online] Available at: http://www://ad.uk.doubleclick.net/adi/N2806 Guardian.ilevel. (November 9, 2012).

Akokpari, J. (2005). Strangers in a strange land: citizenship and the immigration debate in Lesotho. Development Southern Africa, 22(1), 6:87-102.

Benton, S. (2007). Community praised for embracing refugees on Human Rights Day. BuaNews 22 March 2007, P2, Tswane, RSA. Available from the Africa Archives.

Bruce-Briggs, B. (2006). The new class? New Brunswick, NJ: Transaction Books.

Chandler, C.R. \& Tsai, Y.M. (2001). Social factors influencing immigration attitudes; An analysis of data from the general social survey. The Social Science Journal, 38(2):177-188.

Cross, C. (2006). Foreign migration's impact: the skills gap? HSRC Review, 4(3):5.

Dorsten, L.E. and Hotchkiss, L. (2005). Research Methods and Society: Foundation of Social Inquiry. Upper Saddle River, New Jersey: Pearson Prentice Hall.

Espenshade, T.J. \& Calhoun, C.A. (1993). "An analysis of public opinion toward undocumented immigration". Population research and policy review 12:189-224.

Espenshade, T.J. \& Hempstead, K. (1996). Contemporary American attitudes toward U.S. immigration. International Migration Review 30:535-570.

Fetzer, J.S. (2000). Public attitudes toward immigration in the United States, France, and Germany. Cambridge, UK: Cambridge University Press.

Gilbert, A., \& Koser, K. (2006). Coming to the UK: What do asylum-seekers know about the UK before arrival? Journal of Ethnic and Migration Studies, 32(7):1209-1225.

Goetz, S. J. (1999). Migration and local labour markets. The Web Book of Regional Science. Philadelphia, PA: Penn State University.

Haubert, J. \& Fussell E. (2006). Explaining pro-immigrants sentiment in the U.S.: Social class, cosmopolitanism, and perceptions of immigrants. International Migration Review, 40(3):489-507.

Hunter, A. \& Skinner, C. (2001). Foreign migrants working on the streets of Durban: Local Government Policy Dilemmas. School of Development Studies. Durban, RSA: University of Natal.

Johnson, R.B., Onwuegbuzie, A.J., \& Turner, L.A. (2007). Towards a definition of mixed methods research. Journal of Mixed Methods Research, 1(2):112-133, April.

Jonathan, C. L. (1995). Spring, Immigration, Diversity and Canadian Exports. Ottawa, Canada: 25(4):11.

Letseka, M. \& Maile S. (2008). High University drop-out rates: a threat to South Africa's future. Human Sciences Research Council (HSRC). Pretoria, RSA: University of Pretoria.

Marriot, O. (2008). The Internet and healthcare in Somalia: Knowledge is power. Newcastle, UK: University of Newcastle.

O'Neill R. C. \& Viljoen L. (2001). Support for female entrepreneurs in South Africa: Improvement or decline? Journal of Family Ecology and Consumer Sciences, 29(2001): 37-44.

Orford, J., Wood, E., Fischer, C., Herrington, M., \& Segal, N. (2003). Global Entrepreneurship Monitor: South African Executive Report. Cape Town, RSA: University of Cape Town.

Palmer, D. (1996). Determinants of Canadian attitudes towards immigration: more than just racism. Canadian Journal of behavioural Science 28:180-192.

Peberdy, S.A. (2000). Border Crossing: Small Entrepreneurs and Cross-border trade between South Africa and Mozambique. Johannesburg, RSA: University of the Witwatersrand.

Peberdy, S. A. \& Crush, J. (1998). Trading places: Cross-border traders and the South African informal sector. South African Migration Project. Migration series No 6, Idasa: Cape Town.

Quillian, L. (1995). "Prejudice as a response to perceived group threat: population composition and anti-immigrant and racial prejudice in Europe". American Sociological Review, 60(4):586-611.

Rogerson, C.M. (1999). International migration, immigrant entrepreneurs and South Africa's small enterprise economy. [Online] Available: http://www.queensu.ca/samp/sampresources/samppublications/policyseries/policy3.htm. (May 15, 2012).

Scheve, K.F. \& Slaughter, M.J. (2001). Labour market competition and individual preference over immigration policy. Review of Economics and Statistics 83:133.

Simon, R. (1993). Old minorities, new immigrants: aspirations, hopes and fears. In P.I. Rose (Ed.) Interminority affairs in the U.S.: Pluralism at the crossroads. Thousand Oaks, CA: Sage.

Simon, R. \& Lynch, J.P. (1999). A competitive assessment of public opinion toward immigrants and immigration policies. International Migration Review 33(2):455.

Serrie, H. (1998). Immigrant entrepreneurs, ethnic networks and family dynamics. Review in Anthropology, 27(3):213-223.

Sharry, F. (2000). Immigrants' contribution to America. Business Week (New York), 3(3675):16.

SA info. reporter. (2004). Refugees and asylum seekers. [Online] Available: http://www.SouthAfrica.info. (July 20, 2012).

The U.S. Urban Institute (2005). Immigration Studies. [Online] Available: http://www.urban.org. (November 23, 2012).

Welman, C., Kruger, F., \& Mitchell, B. (2005). Research Methodology. 3rd ed. Southern Africa: Oxford University Press.

Zikmund, W.G., Babin, B.J., Carr, J.C., \& Griffin, M. (2010). Business Research Method. 8th ed. Canada: South-Western Cengage. 